\title{
Dichotomy between Primeval and Contemporary Scholars' Role to the Spread of Islam in Yoruba Land: Countervailing Appraisal
}

\section{Abdulkabir Olaiya Suleiman*}

Skola Research Islāmic Foundation, Head Office, Atari Area, Offa, Kwara State, Nigeria

\begin{abstract}
The growth and development of Islām in Yorubaland is avowed due to the determined efforts of some scholars who had laid down their life to broaden the fundamental teaching of Islām day and Night. Meanwhile, painstaking assessment has dichotomized the idealism of the eminent scholars of Yesterday and acclaimed scholars of today in the light of the original teaching of Islām. This paper agrees that primitive scholars were conversant of heavenly instruction given by Allāh and they were very much enthralling onto it. Their conviction in line of duty is between faith in and fear of Allāh to have perceived all trials as tentative consequence. On a contrary, this 21 st century witnesses a lot of calamitous and ruinous acts engendered by today's scholars in the nukes and crannies of Yorubaland. The manuscript specifically laid emphasis on some religious leader and so called scholars to have turned to the agent of corruption, manufacturer of ritual Money, builder of monster, contractor of part of human body and backbone of political henchman. An attempt is, therefore, made in this paper to juxtapose the traits and contributions of primordial scholars to the growth and development of Islām in Yorubaland in comparison with the agnostic, wickedness, dissipated, debauched and intolerable peculiarity of the contemporary scholars. The paper concludes that, some contemporary scholars has either misinterpreted the divine teaching of Islām or belittle the gravity of sin and severe wrath of Allah as a reward of depravity.
\end{abstract}

Keywords: Primordial scholar; Debauched; Dichotomy; Juxtaposition; Countervailing appraisal

\section{Introduction}

The spread of Islām in Yorubaland was instigated with concerted efforts of some renowned scholars who contributed immeasurably to the growth and development of Islām through dynamic teaching, learning and resourceful $\mathrm{da}^{c}$ wah. The religion of Islām was spread peacefully by the ancient Imām, itinerant Sufi, and eminent 'ulamah blended with local Qur'ānic School founded in various locations across the country in Nigeria. These scholars carried out series of religious activities to elevate the pennant of Islām without intention of becoming famous or acquiring reward from people. Contrary to the tremendous role of the ancient scholars, the contemporary scholars has not availed the advantage of promoting pious traits, splendor and devoutness of Islām which was constructed with sweat and vibrant exertion of the primeval scholars.

Adebayo [1] submits that every society, be it primitive or modern, simple or complex, has a process through which its cultural values, norms and behavioural patterns are transmitted to its young and potential members. Islāmization of knowledge is not a new concept in Islām. There have been individual efforts by Muslim scholars to change the destiny of Muslim education for the better even before the colonial invasion of the Muslim world.

Meanwhile, the introduction of Islām to Yoruba society in the 18th century, Islāmic literacy had considerably attracted the attention of the Muslims to improve and practice Islamic religious activities. With the spread of Islām, many Muslims mixed the Islāmic practice with those of their traditional beliefs, which they inherited from their ancestors, and which contradict the teaching of Islām [2].

Pertinently, the ancient scholars were reported to have specialized on either spreading the doctrines of Sufism in their milieu or traveled wild and far on propagating Islāmic Jurisprudence. While some of them focused on (Khalwa) ascetic seclusion others continue on proselytizing the message of Allāh as calisthenics and core curriculum activities according to the instruction given in the Qur'ān which says.
"And who is better in speech than one who invites to Allah and does righteousness and says, "Indeed, I am of the Muslims" (Yusuf Ali, Qur'ān 41:33)".

However, the history of Yoruba contact with Islām and the farreaching impact that Islām has had on them and their language, is a subject that has received elaborate coverage in scholarly literature. While there is ample record of the massive spread of Islām among the Yoruba from the second decade of the nineteenth century as a result of the emergence of Ilorin as a frontier state this served as a springboard for propelling the jihād of 'Uthmān b. Füdõ southwards [4].

To this effect, the approach of prehistoric 'Ulamah in propagating the word of Allah is dynamic and observable to the point that the foundation laid down by these pragmatic Scholars which is still continuing till today started before $19^{\text {th }}$ Century under the colonial stigmatization in Nigeria. Meanwhile, the spotlight of these antediluvian scholars is but to preserve the religion with their life from antagonistic rivalry as contains in Qur'ān 33:23 which read thus;

Among the Believers are men who have been true to their covenant with Allah: of them some have completed their vow (to the extreme), and some (still) wait: but they have never changed (their determination) in the least. (Yusuf Ali: Qur'ān 33:23).

Consequently, before and under colonial rule, Islāmic schools were

*Corresponding author: Suleiman AO, Skola Research Islāmic Foundation Head Office, Atari Area, Offa, Kwara State, Nigeria, Tel: +2348033627295; +2348077626050; E-mail: afakabirskola@gmail.com

Received February 01, 2017; Accepted March 01, 2017; Published March 10 2017

Citation: Suleiman AO (2017) Dichotomy between Primeval and Contemporary Scholars' Role to the Spread of Islam in Yoruba Land: Countervailing Appraisal. Intel Prop Rights. 5: 178. doi: 10.4172/2375-4516.1000178

Copyright: (๑) 2017 Suleiman AO. This is an open-access article distributed under the terms of the Creative Commons Attribution License, which permits unrestricted use, distribution, and reproduction in any medium, provided the original author and source are credited. 
organized for the purpose of teaching people how to read and write in Arabic. Naturally, the school began with the education of the family members of the chief's compound (Baale) which gradually culminated into the conversion of the chief and members of the ruling elite in most Yoruba communities. The Muslims, in their preaching, condemned the practice of wood sculpture of Yoruba deities enshrined in the belief system of the people [5].

Evidently, one of the major scopes used to spread Islāmic doctrine in Yoruba society is thus, they made people to believe that one can become a Muslim without understanding Arabic or other teachings of Islām. It is believed among the Muslims, that the simple affirmation that "There is no God but Allāh, and Muhammad is the messenger of God" is sufficient for a person to be accepted into the fold of Islām. For this reason, many non-Muslims began to accept Islām because they wanted to be associated with a new and foreign religious ideology [6].

Having examined the ancient scholars' involvement towards the growth and development of Islām in Nigeria, it is necessary to evaluate the position of contemporary scholars of this $21^{\text {st }}$ Century especially when the world is globally linked. Evidently, modernization has crept into the activities of today scholar and as a result of getting huge money in return of $\mathrm{Da}^{c}$ wah or becoming influential in the society, they turn around twisting the word of Allāh from the pathway instituted by their primordial scholars which they inherited.

Congruence to the assertion abounds, the growth and development of Islāmic activities in Nigeria which was instigated with strenuous efforts of some primitive scholars have been wipe out by the contemporary scholars. With thorough justification, this manuscript scrutinizes the influence of Islāmic scholars of yesterday and today towards the upsurge of both Islāmic education and $\mathrm{Da}^{c}$ wah activities in Nigeria.

\section{Literature Review}

It is pertinent to preserve available literatures for the incoming generation to observe the resolute contributions of the ancient scholars to the growth and development of Islam in Nigeria. This is important as a corollary of the concerted effort of the eminent scholars and their role towards Islāmic literacy has left an indelible mark on Yoruba sociocultural and political landscape [7].

Fafunwa [8] confirms that Qur'ānic education reached West Africa subcontinent in the eighth century C.E. Nevertheless, it was about the 13th century that Islamic faith and education gained fame and acceptance in the various West African kingdoms, such as the KanemBornu and others. Lemu [9] propounds that Islam first entered West Africa through trans-Saharan Trade in the $9^{\text {th }} / 10^{\text {th }}$ century. It spread among the rulers and the urban population and then gradually into the rural areas. Scholars established Qur'ānic schools and for many centuries up to the colonial period, Islāmic schooling was the formal educational system in Northern Nigeria.

Robinson and Smith [10] points out that in the early 14th Century, Islam was brought into Hausa land by traders and scholars who came from Wangarawa to Kano in the reign of Ali Yaji (1349-1385). The religion later spread to other parts of the country through the Jihad of Uthman Dan Fodyio in 1804 reviving and purifying Islām, to eliminate syncretic beliefs and rituals, and to remove all innovations contrary to the Qur'ān and Shari'ah, and also to encourage less devout Muslims to return to orthodox and pure Islām.

According to Jangebe [11] Islāmic reformism has been the prime concern of Muslim scholars and intellectuals since the $18^{\text {th }}$ century C.E. and as a means to arrest the mushrooming and all around decay in their societies. In Nigeria, Muslims are plunged into backwardness because of the colonial legacy and the rising of un-Islāmic practices (innovations) that have been instrumental in instigating serious problems in entire country.

In spite of the corrosive effects of the Western civilization on our cultural legacies, the tradition of Qur'annic education in southern Nigeria still remained hesitant and non-withering. The South-Western Nigeria is predominantly occupied by the Yoruba speaking people and it cuts across Ekiti, Lagos, Ogun, Ondo, Osun, Oyo States and most parts of Kwara State. In the 18th century, there were about fourteen major kingdoms in the South Western Part of Nigeria. They included Oyo Kingdom, Ife kingdom, Ekiti, Igbomina, Ijana, Ijebu, Ijesha, Egba, Egbado, Ketu, Ondo, Owu and Sabe kingdom [12].

Meanwhile, during this time like other regions of West Africa, the Qur'anic School was a small facility, usually attached to a mosque where children learned the Qur'ān and the basic duties of every Muslim. These schools were mostly community-based or societal initiative programme situated at the Mosques for the continuous purpose of Qur'ānic learning, while in some cases the residences of the $\mathrm{Mu}^{\mathrm{c}}$ allim as well as under tree shades were used as schools [8]. Oseni [13] affirms that, it is hardly any eminent scholar of Arabic and Islāmic Studies in Edo, Ekiti, Kogi, Ondo, Osun, Oyo, Ogun and Lagos states of Nigeria who does not have an Ilorin Shaykh as his teacher. For instance one should recall the thousands of Arabic and Islāmic scholars trained by Shaykh Taj al-Adab, Shaykh Muhammad Kamalu-deen al-Adabi, Shaykh Salman Ake, and Shaykh Adam Abdullah al-Ilori and their disciples.

Hunwick [14] accentuates the fact that Ilorin provided an effective bridge of Islāmic learning between the centres of Hausaland and Bornu and developed new centres of Islāmic learning in Yorubaland such as Ibadan, Ijebu Ode, Abeokuta and Lagos. For instance, Sheikh Adam Abdullah Al-llory (1912-1992) a prominent Yoruba Muslim teacher and preacher in Lagos wrote several books in Arabic language that has enriched the knowledge of the growth of Islām among Yoruba Muslims and which up till today have been found useful by modern African historians in the documentation and reconstruction of the history of the Yoruba Muslims in Nigeria

Maigida [15], agrees that Islamic education became a more appropriate nomenclature for education that is not only Quranic, but became integrative of other scriptures like the Hadith (sayings of the Prophet of Islam), Fiqh (Islāmic jurisprudence) from where the Shari'ah was derived; to broaden the horizon of the Muslims learners in terms of knowledge.

However, the contribution of scholars to the development of Qur'anic education has made Ilorin to be regarded as a citadel of knowledge and the religious heartbeat of southern Nigeria. Most evidently, the efforts of Sheikh Kamāliddīn Al-Adabiy and Sheikh Âdam Al-Ilory towards the Islāmic-cum-Qur'ānic scholarship cannot be overemphasized. The duo were scholars of international repute and recipients of international awards in the field of Islāmic scholarship, and produced students who were renowned and profound in Qur'ānic scholarship, as well as dacwah and academic erudition, locally and internationally.

Alaro and Abdul-Hameed [16] explains that Qur'ānic education in Islām unequivocally derived its origins from the stringent and symbiotic status of religious instructions. This therefore explains the 
importance of Qur'ānic education in any Islamic society. According to their assertion,

"the efforts of Muslim clerics and scholars of the coast lane of Nigeria like Lagos, who had earlier contact with foreigners and traders from the Islamic world, the history of Qur'anic education in Southern Nigeria would be incomplete without the phenomenal efforts of the Ilorin emirate and her scholars, which cement the status of Qur'anic education in the zone".

Opeloye and Jimoh [17], concludes Qur'ānic education had been well established before the colonial era in major cities of the southern states of Nigeria like Ibadan, Abeokuta, Ijebu-Ode as well as Lagos, which housed scholars from far and wide with established traditional study circles and Madāris. Meanwhile, Muhammad Ali Al-Isham [18] opines that it is strange that these shortcoming exist among some of those who are regarded as playing an active role in Islāmic Da'wah and who are involved in the propagation of practical message that, in most cases, provides an awareness and understanding of Islāmic teachings and value following true guidance. Yet it seems that the overwhelming nature of their work or perhaps carelessness or forgetfulness, has caused some Islāmic scholars to fall into the trap of these errors whether knowing of otherwise.

Therefore, the principal objective of this research is to investigate on the efficient mode of Dawah and dynamic contributions of the ancient and contemporary scholars to the growth and development of Islam and to examine the factors which dichotomize their Islamic conception.

\section{Dichotomy between Ancient and Contemporary Scholars}

It is pertinent to note that Islām has laid foundational references for all humanities to subsist under the shade of the glorious Qur'ann and the epitome tradition of Prophet Muhammad (SAW). The Qur'àn and Hadith as divine manuscript made it easy for painstaking appraisal and therefore divulged axiomatic dichotomies between approaches, qualities, mannerism and trait of the ancient Islāmic scholars and scholars of this $21^{\text {st }}$ century. Some of the differences are highlighted below;

\section{Lack of Islāmic knowledge}

One of the major ill-fated contrivances which dichotomized the traits of the ancient scholars from the contemporary once is the acquisition and effectiveness of knowledge. Acquiring and possessing knowledge ('ilm) has a great position in Islāmic fundamentalism, as knowledge is highly encouraged by the Holy Qur'an and Muslim scholars. Qur'ān (33:9) was recorded to have said:

Is one who is devoutly obedient during periods of the night, prostrating and standing [in prayer], fearing the Hereafter and hoping for the mercy of his Lord, [like one who does not]? Say, "Are those who know equal to those who do not know?" Only they will remember [who are] people of understanding. (Yusuf Ali, Qur'ān 33:9)

This by implication shows that knowledge, attainment of which is obligatory upon all Muslims covers the sciences of theology, philosophy, law, ethics, politics and the wisdom imparted to the Ummah by the Prophet (SAW). To this effect, the significance of knowledge in Islam affords the scholars to have occupied a noble status in Islam, and which is higher than the position of others in this world and in the Hereafter as emphatically mentioned in Qur'ān (35:28) which read thus,
And among people and moving creatures and grazing livestock are various colors similarly. Only those fear Allah, from among His servants, who have knowledge. Indeed, Allah is Exalted in Might and Forgiving. (M. Taqi-ud-deen and M. Khan Qurān 35:28) [19].

Historically, the scholars of yesterday took knowledge as a decisive weapon not only to wage war for Islāmic $\mathrm{Da}^{c}$ wah but also to set a breadline against indiscipline, corruption and sleaziness. The truth is that many of today's scholars is but either neglect acquisition of Islāmic knowledge as first step of becoming scholar or have copious knowledge of Islam but decided not to use it because of circumstances only known to them.

In the light of this, seeking knowledge is an obligation upon every Muslim and the superiority of the one who has knowledge over the one who merely worships is like the superiority of the moon over every other heavenly body. The ancient scholars affirm that Knowledge is more important than wealth or property and they works towards getting the abundance reward from Allāh in the day of resurrection but the contemporary scholars initiate irreligious catchphrase that: "Knowledge without money is useless"

\section{Misconception about Qur'ānic verse}

Despite the fact that, there is no doubt in the authenticity of Qur'ān and the hadith of prophet Muhammad peace be upon him, yet differing interpretations of Qur'ān remain one of the primary divider dissociates the primitive scholars from the modern scholars. While the ancient scholars strive to interpret Qur'ān with contextual meaning for the benefit of religion and it advocates, the contemporary scholars took Qur'ānic verses out of context to confuse crooked cultural norms with Islāmic teachings in order to promote their doctrine and indoctrinate people with their heinous mannerism.

Meanwhile, Qur'ān emphatically responds to the misconception of the pseudo Muslims who plunged strange interpretation alien to the superlative teachings of the prophet and the primitive exegeses. To this effect, Qur'ān (4:82) say;

Then do they not reflect upon the Qur'an? If it had been from [any] other than Allah, they would have found within it much contradiction (M. Taqi-ud-deen and M. Khan, Qurān 4:82).

Evidently, one of the prime reasons that led people to have disconcerted opinion for some verses of the Qur'an is that, people have various sources for acquiring knowledge of Islām which most of it negates the divine teaching of the glorious Qur'an. Had it been everyone has developed his concepts, ideology and philosophy of religious belief from teaching of Islām there won't be any disagreement in fundamental of Islām. Qur'ān (3:7) highlights the misconception of people toward the interpreting the word of Allah, thus,

It is He who has sent down to you, [O Muhammad], the Book; in it are verses [that are] precise - they are the foundation of the Book and others unspecific. As for those in whose hearts is deviation [from truth], they will follow that of it which is unspecific, seeking discord and seeking an interpretation [suitable to them]. And no one knows its [true] interpretation except Allah. But those firm in knowledge say, "We believe in it. All [of it] is from our Lord." And no one will be reminded except those of understanding (M. Taqi-ud-deen and M. Khan, Qurān 3:7 ).

The verse of the Qur'an is comprehensible to the noble mind except for the contemporary scholars that deliberately uses the Qur'ān to support their heinous belief and the narrow minded will follow them dogmatically. 


\section{Covetousness and cupidity}

Covetousness is the opposite of contentment and is the abject desire and wanting to obtain something in circumstance beyond explanation. Islām condemned any act of desirous and greediness because it is the funnel of insatiability that can tempt Muslims out of religious bond.

Categorically, the scholars of yesterday engulfed their soul with abstemious determination which made them to be contented with a little or nothing. They were reported to have been domiciled in a blimpish and outmoded abode without enough or desire to accept donation from devilish income. Meanwhile, 'Ulamāh of today turn to mendicant, vagrant and street beggar. Because of money, some of them belittle their personality to gain grand from affluent people.

Categorically, the scholars of today did not consider Allāh as the only provider and sustenance for his servants. To their belief, your strived will take you out of impecunious situation. There is a common saying popular among this contemporary scholars such as "if you don't eat forbidden food when where will you get sanitary one, help yourself to activate your destiny"

On a contrary assertion, the scholars of yesterday acknowledge the favour of Allah on his servant as the divine provider for all humanity as mention in the glorious Qur'ān, thus;

Say, "Come, I will recite what your Lord has prohibited to you. [He commands] that you not associate anything with Him, and to parents, good treatment, and do not kill your children out of poverty; We will provide for you and them. And do not approach immoralities - what is apparent of them and what is concealed. And do not kill the soul which Allah has forbidden [to be killed] except by [legal] right. This has He instructed you that you may use reason" (M. Taqi-ud-deen and M. Khan, Qur'ān 6:151) [19].

The verse above is one of the prudence messages of the Qur'ann, illuminating ambitious greed which has come to dominate all human societies in our technological age. This verse highlights the greedily striving of mankind for an increase in benefits, be they tangible or intangible, real or illusory. It denotes man's obsessive striving for more and more comforts, more material goods and greater power over his fellow-men or over nature, and unceasing technological progress.

Due to the covetousness of the so call civilized scholars, they do encourage people to acquire mammoth money irrespective of the source. As a result of this avaricious idiosyncrasy, many of the scholars hearten ill-faith people either to do ritual money or to involve in inimical and contraband services such as smuggling of cocaine, merchandizing part of human body or structuring political muggers with spiritual benchmark. They are forgetting the verse of the glorious which read thus,

So worship what you will besides Him." Say, "Indeed, the losers are the ones who will lose themselves and their families on the Day of Resurrection. Unquestionably, that is the manifest loss" (Yusuf Ali, Qurān 39:15).

\section{Political involvement}

Islām is a religion of peace encompasses all scope of life including social, economic and political fundamentalism. Over the years, Nigerian government has failed to harness the vast human and material resources at its disposal to break the cycle of poverty and autocracy that has characterized it since independence in 1960 [20]. Meanwhile, the role of contemporary ${ }^{\text {cUlamah }}$ to the political cataclysm cannot be over emphasized.

In the olden days, the 'Ulamah are the respected personality because they adhere to the direction of Shari'a even their cloth may be frumpy, dwelling in antiquated house or eating decrepitude food yet they lived as a sentinel to checkmate politician and direct them to discharge epitome leadership for the people. These ancient scholars stick with the fact that, the world has tainted with dishonesty and corrupt politician as prescribed in the glorious Qur'ān thus,

Corruption has appeared throughout the land and sea by [reason of] what the hands of people have earned so He may let them taste part of [the consequence of] what they have done that perhaps they will return [to righteousness] (Yusuf Ali, Qurān, 30:41).

Meanwhile, like the social and economic life, the political life of Islam is based on sound spiritual and moral foundations, and is guided by Divine instructions. The political system of Islām is unique in its structure, its function, and its purpose. It is not pragmatic, instrumental or theocratic whereby a certain class of people assumes divine rights, hereditary or otherwise, and poses above other citizens, beyond accountability. Nor is it a proletariat whereby some revengeful laborers capture power. It is not even democracy in its popular sense. It is something different from all that. To appreciate the political outlook of Islam one has only to know that it is based on the Islāmic principle [21]

However, the scholars of this century agree to the propounded slogan of deceitful politician which read thus; "one has to die to save million because Politic is a game of blood." As a result of this, the politician twirled scholars from being personality guided with divine scripture to political henchmen. The countenance of 'Ulamāh for the political Godfather in Yorubaland has augments the command of corruption in Nigeria.

In addition, many of so call religious leaders have become political demigod in the pursuit of deceptive appointment and fraudulent contract form government. In return of these favour, many of them has to kill or provide part of human body for politician to succeed in their political aspiration. To this effect, many political elites, past and present, have accumulated personal fortunes through resilient, deeply rooted systems of political patronage that are wired into the booming oil industry in the south [22]. Meanwhile, the glorious Qur'ān has ardently grimaced any unjust killing and act of fraudulence that can asphyxiate the innocent people, thus,

Say, "My Lord has only forbidden immoralities - what is apparent of them and what is concealed - and sin, and oppression without right, and that you associate with Allah that for which He has not sent down authority, and that you say about Allah that which you do not know." (Yusuf Ali, Qurän 7:33).

\section{Conclusion}

The Qur'ān is the last and final revelations from Allāh. It consists of direct words of God that revealed through the arch Angel Jibril to Prophet Muhammad SAW, the final prophet of Islam, which has been preserved by the ancient scholars more than 1400 years ago. This paper discovers that the problem of repugnant scholars is widespread in not only Yorubaland but also Nigeria as a whole. In essence, some of the acclaimed scholars cannot even read the verse of the Quran clearly but have capacity of memorizing more than 7 pages incantation off hand.

In the sense of absolute contradiction, the contemporary scholars turned either to forecaster, fortuneteller, palmist, clairvoyant, soothsayer or astrologer without any prolific knowledge except deceptive prediction. Some of these scholars hide under the illusion of 
Citation: Suleiman AO (2017) Dichotomy between Primeval and Contemporary Scholars' Role to the Spread of Islam in Yoruba Land: Countervailing Appraisal. Intel Prop Rights. 5: 178. doi: 10.4172/2375-4516.1000178

Sufism to deceive people with false inspiration.

There is no gainsaying that many of the contemporary scholars have completely deviated from the straight-path, the path of the companion of the prophet and the ancient scholars, the path which Allah designed for the scholars of truth to follow.

\section{Recommendation}

1. The contemporary scholars should put the fear of Allāh in all their doings in this ephemera life to enable them to gain eternal bliss in the Day of recompense

2. The scholars as the successor and replica of Prophet of Allāh should at least live a model and exemplary life in concordance with Qur'ānic law and tradition of the prophet SAW.

3. The Council of ${ }^{c}$ Ulamah in Nigeria should launch a committee of $\mathrm{Da}^{c}$ wah to checkmate the transgression of so called 'Ulamah.

4. If we take our religion serious, every individual Muslim must try to understand the Qur'ānic context by reading it and act accordingly in all aspects of their life.

5. All Muslims should try as much as possible to search for religious knowledge which will enable them to understand the fundamental of Islām

6. Islāmic organization should try to provide pamphlet, Magazine, and Islāmic book that will assist individual to know history and teachings of Islām.

\section{References}

1. Adebayo RI (2004) Islāmization of knowledge: its inevitability and problems of practicability in Nigeria Published by Muslim Education. Quarterly Autumn/ winter 21: 4

2. Mahmud K (1983) The Arabic Literary Tradition in Nigeria" Nigeria Magazine No 14: 37-54.

3. Yusuf A (1988) The Holy Qur'ān Text Translation and Commentary Dar-AlArabia Publishing Printing and Distribution Beirut Lebanon. Tahrike Tarsile Qur'an, Nigeria.

4. Horton JA (1969) West African Countries and Peoples Edinburgh 1868 reissue Cambridge: Cambridge University Press 196: 144.

5. Nduka O (1980) Moral Education in the Changing Traditional Societies of SubSaharan Africa. International Review of Education 26: 2.

6. Ayandele EA (1992) The ljebu of Yorubaland: Politics Economy and Society lbadan: Heinemann Educational Books.

7. Oladiti AA (2014) Reconsidering the influence of Islam on Yoruba cultura heritage 1930-1987. American International Journal of Social Science 3: 36.

8. Fafunwa AB (1974) History of Education in Nigeria. London George Allen and Unwin 52.

9. Lemu BA (2002) Religious Education in Nigeria-A Case Study Islamic Educational Trust Nigeria. In Teaching for Tolerance and Freedom of Religion or Belief. Report from the preparatory Seminar held in Oslo December $7^{\text {th }}-9^{\text {th }}$ 2002.
10. Robinson D, Smith D (1979) The Jihad of Uthman and the Sokoto caliphate Sources of the past: Case studies of five nineteenth-centuries African Societies p: 125.

11. Jangebe HA (2015) Islamic Reform in Nigeria: The Contribution of Sheikh Abubakar Mahmud Gumi International Journal of Humanities and Social Science 5: 176.

12. Adebayo RI (2005) Muslim Educational Reform in the South Western Nigeria in Muslim Educational Reform Activities in Nigeria. A joint publication of the IIIT (Nigeria) and Faculty of Education Bayero University Kano Nigeria 128-142.

13. Oseni ZI (2013) Prose And Drama In Nigerian Literature In Arabic: The Journey So Far Being Inaugural Lectures Delivered at University of Ilorin. Series fiftythird 53: 1.

14. Hunwick J (1997) The Arabic Literary Tradition of Nigeria. Research in African Literatures 28: 215.

15. Maigida AY (2012) Historical Foundations Of Islamic Education In Nigeria: A Contemporary Assessment 5.

16. Alaro AA, Abdul-Hameed U (2015) Post-colonial Qur'ānic Education in Southern Nigeria.

17. Opeloye MO, Jimoh SL The Yoruba Muslims of Nigeria and the Glorious Qur'an NATAIS journal 7: 67.

18. Al-Isham MA (1996) The true Islamic personality as define in the Quran and Sunna translated by Nasirudeen Al-Kattab International Islamic Publishing House 101.

19. Hilali MT, Khan MM (2015) The Translation of the meaning of the Noble Qur'ān in the English Language king Fahd Complex for the Printing of the Holy Qur'ān Madinah K.S.A.

20. Idada W, Uhunmwuangho SO (2012) Problems of Democratic Governance in Nigeria: The Way Forward Kamla-Raj. J Sociology Soc Anth 3: 49-54.

21. Abdalati H (1997) Islam In Focus. Amana Publications Tucker Strees Beltsvalle Maryland 254.

22. Hoffmann LK (2014) Who Speaks for the North? Politics and Influence in Northern Nigeria The Royal. Institute of International Affairs Chatham House 7. 